\title{
Preliminary placement and new records of an overlooked Amazonian tree, Christiana mennegae (Malvaceae)
}

\author{
Rafael G Barbosa-Silva ${ }^{\text {Corresp., } 1,2 \text {, Thales Silva Coutinho }}{ }^{3}$, Santelmo Vasconcelos ${ }^{1}$, Delmo Fonseca da Silva ${ }^{4}$, \\ Guilherme Oliveira ${ }^{1}$, Daniela C Zappi ${ }^{1,2,5}$ \\ 1 Instituto Tecnológico Vale de Desenvolvimento Sustentável, Belém, Pará, Brazil \\ 2 Coord. Botânica, Museu Paraense Emílio Goeldi, Belém, Pará, Brazil \\ 3 Programa de Pós-graduação em Biologia Vegetal, Departamento de Botânica, Universidade Federal de Pernambuco, Recife, Pernambuco, Brazil \\ 4 Parque Zoobotânico, Departamento de Ferrosos Norte, Gerência de Meio Ambiente-Minas de Carajás, Parauapebas, Pará, Brazil \\ 5 Programa de Pós-graduação em Botânica, Instituto de Ciências Biológicas, Universidade de Brasília, Brasília, DF, Brazil \\ Corresponding Author: Rafael G Barbosa-Silva \\ Email address: rafa.g29@gmail.com
}

Christiana mennegae is a phylogenetically enigmatic taxon and represents a case in point of a species whose presence escaped the radar of the Amazon lists and the Brazilian Flora project. Here we expand its distribution by adding new records from Peru and overlooked ones from Brazil. To investigate its phylogenetic placement in the Brownlowioideae, part of the rbcL gene of the plastid and the intergenic ITS2 region were sequenced. Macro- and micromorphological investigation of features of $C$. mennegae using SEM of foliar, flower, fruit and seed structures are presented. A lectotype for the name is designated here. The morphology of trichomes revealed five types of trichomes ranging from glandular to branched and unbranched and we also report stomata on the seed surface for the first time in Brownlowioideae. Christiana mennegae and C. africana were recovered as sister species in the phylogenetic analysis, albeit with low to moderate support, and more species of this and closely related genera must be sampled and analyzed in order to obtain a clearer picture of the group's affinities and relationships. We provide an update of its conservation status from Vulnerable to Least Concern. We also highlight the need for investment in the digitization of biological collections, botanical capacity building at the local level and the importance of the availability of online literature to speed the study of Amazonian plant diversity 
1 Preliminary placement and new records of an

2 overlooked Amazonian tree, Christiana mennegae

3 (Malvaceae)

4

5

Rafael Gomes Barbosa-Silva ${ }^{1,2}$, Thales Silva Coutinho ${ }^{3}$, Santelmo Vasconcelos ${ }^{1}$, Delmo Fonseca da Silva ${ }^{4}$, Guilherme Oliveira ${ }^{1}$, Daniela Zappi ${ }^{1,2,5}$

${ }^{1}$ Instituto Tecnológico Vale de Desenvolvimento Sustentável, R. Boaventura da Silva 955, 66055090, Belém, PA, Brazil

${ }^{2}$ Museu Paraense Emílio Goeldi, Coord. Botânica, Av. Perimetral 1901, 66077-830, Belém, PA, Brazil.

3 Programa de Pós-graduação em Biologia Vegetal, Departamento de Botânica, Universidade Federal de Pernambuco, CEP 50670-901, Recife-PE, Brazil

${ }^{4}$ Parque Zoobotânico, Departamento de Ferrosos Norte, Gerência de Meio Ambiente-Minas de Carajás, Brazil

5 Programa de Pós-Graduação em Botânica, Instituto de Ciências Biológicas, Universidade de Brasília, DF, 70910-900, Brazil.

Corresponding Author: Rafael Barbosa-Silva

Email address: rafa.g29@gmail.com

\section{Abstract}

Christiana mennegae is a phylogenetically enigmatic taxon and represents a case in point of a species whose presence escaped the radar of the Amazon lists and the Brazilian Flora project. Here we expand its distribution by adding new records from Peru and overlooked ones from Brazil. To investigate its phylogenetic placement in the Brownlowioideae, part of the rbcL gene of the plastid and the intergenic ITS2 region were sequenced. Macro- and micromorphological investigation of features of $C$. mennegae using SEM of foliar, flower, fruit and seed structures are presented. A lectotype for the name is designated here. The morphology of trichomes revealed five types of trichomes ranging from glandular to branched and unbranched and we also report stomata on the seed surface for the first time in Brownlowioideae. Christiana mennegae and C. africana were recovered as sister species in the phylogenetic analysis, albeit with low to moderate support, and more species of this and closely related genera must be sampled and analyzed in order to obtain a clearer picture of the group's affinities and relationships. We provide an update of its conservation 
status from Vulnerable to Least Concern. We also highlight the need for investment in the digitization of biological collections, botanical capacity building at the local level and the importance of the availability of online literature to speed the study of Amazonian plant diversity.

Keywords: Barcode, Brownlowioideae, Malvales, rain forest, SEM, vascular plants.

\section{Introduction}

The exploration of the Amazon rainforest has sparked scientific curiosity since the travels of naturalists such as Alexandre Rodrigues Ferreira, La Condamine, Spix and Martius, Schomburgk, Spruce, Wallace and Bates (La Condamine \& Godin des Odonais, 1808; Spruce 1908; Ferreira et al., 2008; Spix \& Martius, 2013; Hemming, 2015; Schomburgk \& Roth, 2017). The stunning variety of life forms, coupled with the difficulty of accessing vast areas of the biome has led to repeated efforts to quantify its diversity (Black et al., 1950; Pires et al., 1953; Gentry, 1988; Hubbell et al., 2008; Milliken et al., 2010; ter Steege et al., 2016; Cardoso et al., 2017). Recent studies indicate that the lowland Amazon region is home to 14,003 seed plant species (Cardoso et al., 2017). Despite the global importance of the Amazon Forest, the information deficit is still high, and knowledge is fragmentary, with vast areas still poorly known (BFG, 2018; Hopkins, 2019), and some of them already destroyed (Piontekowski et al., 2019). The number of species based on herbarium data and/or large online datasets has changed little and spatial collecting gaps persist (Forzza et al., 2012; BFG, 2015; Hopkins, 2019).

Attempts to accelerate the work to describe the Amazon's plant diversity include the development of massive online data repositories (Canhos et al., 2014; Morim \& Lughadha, 2015; BFG, 2018). Both herbarium collections and literature sources have been included in this endeavor (Ebach et al., 2011; Funk, 2018) and, in the age of big data, a plurality of sites and online libraries help to minimize this taxonomic impediment (Schonfeld, 2003; Gwinn \& Rinaldo, 2009). However, botanical studies are still scarce and do not cover the taxonomic complexity of a megadiverse biome such as the Amazon (Hopkins, 2019). Access to existing studies is essential for the advancement of this knowledge.

Christiana DC. (Malvaceae) is included if the subfamily Brownlowioideae on phylogenetic evidence and due to morphological features such as sepals fused to form a campanulate calyx, stamens numerous, free, anthers basally dilated with apically contiguous thecae and many- 
65

66

67

68

69

70

71

flowered bicolor units (Bayer et al., 1999; Bayer \& Kubitzki, 2003). The genus comprises five species worldwide, four of them tropical, and was described by De Candolle (1824). The type of the genus, Christiana africana DC., is a tropical tree with similar distribution to the kapok tree (Ceiba pentandra (L.) Gaertn.). A second species, C. macrodon Toledo (1952), was described from the Atlantic Rainforest of the state of São Paulo. Kubitzki (1995) widened the circumscription of the genus to include two other Neotropical species (C. mennegae (Jans-Jac. \& Westra) Kubitzki and C. eburnea (Sprague) Kubitzki, as well as the Polynesian C. vescoana (Baill) Kubitzki).

Despite the fact that Kubitzki (1995) mentioned the occurrence of Christiana mennegae in Brazil, this was overlooked by successive editions of the Catalog of Brazilian Plants and Fungi (Forzza et al., 2010), List of Species of the Brazilian Flora (Lista de Espécies da Flora do Brasil, 2008-2015), BFG 2015 (Brazil Flora Group [BFG], 2015) and the Brazilian Flora 2020 (Flora do Brasil 2020). In addition, Secco (2000) recorded Asterophorum mennegae Jans.-Jac. \& Westra (= C. mennegae) for the state of Pará, although his publication was alsooverlooked. Christiana mennegae is not listed in the Amazon tree list (ter Steege et al., 2019), nor was it recorded in the list of Amazonian seed plant species (Cardoso et al., 2017). Meanwhile, this species has remained as Vulnerable in the Red List since 1998 (World Conservation Monitoring Centre., 2017).

Morphological studies with other genera of Brownlowioideae have explored characteristics such as seed coat and the type of trichome on the leaf surface for the delimitation of species (Chung et al., 2012), and such characters were still unknown for Christiana. In addition, phylogenetic sampling of the Brownlowioideae is still limited to only one species per genus, with the genus Christiana represented only by Christiana africana DC. (Bayer et al., 1999; Hernández-Gutiérrez \& Magallón, 2019). Thus, Christiana mennegae is another rare, phylogenetically enigmatic and poorly understood tree species from the Amazon (Cardoso et al., 2015). During fieldwork linked to a project to study the natural capital of the Amazon forest in the region of Carajás, our attention was drawn to the existence of an unidentified malvaceous tree by DS, one of the authors of this paper, at the Parque Zoobotânico in the Floresta Nacional de Carajás (FLONA Carajás) that turned out to be $C$. mennegae. The specimen collected in the area had morphological characteristics that matched the genus Christiana, such as flowers with a fused calyx but with free lobes, numerous stamens and fruits with glabrous and glossy endocarp, carrying a single, variegated seed per locule. 
94 With the purpose of clarifying and complementing the knowledge regarding Christiana 95 mennegae, we provide additional data on its morphology and phylogenetic affinities to establish 96 with certainty its presence in Brazil and Peru. 
97

98

\section{Material and methods}

Taxonomic treatment. The morphological description was mostly based on herbarium material supplemented by measurements from living plants collected in recent expeditions to the Floresta Nacional de Carajás (FLONA Carajás/63324-1), Pará state, Brazil. Several branches of the specimens were examined in the field to be sure that the species is dioecious. Herbarium material was rehydrated to dissect and illustrate reproductive structures. We analysed specimens from the HCJS and MG and searched the web for records available in REFLORA (2020), Tropicos (2020) and Virtual Herbarium of Flora and Fungi of Brazil (INCT, 2020). We found specimens deposited in F, IAN, INPA, K, MG, MO, P, RB, U and VEN herbaria (acronyms according to Thiers 2020, continuously updated). Morphological terminology follows Harris \& Harris (2001) and Radford et al. (1974).

Distribution map and Conservation status. The distribution map was prepared using QGIS (QGIS Development Team, 2016) with coordinates obtained based on information available from herbarium labels. All studied specimens were plotted on the map. The IUCN conservation status (IUCN, 2012) was ascertained using the GeoCat Tool (Bachman et al., 2011).

SEM. Petioles, abaxial surface of mature leaf-blades, external surface of the calyx, epicarp and seed were dried and extracted from each voucher specimens deposited at MG (Zappi et al. 4562 and Barbosa-Silva et al. 1424). These structures were mounted on stubs using press-on, doublesided tape tabs, examined with a Scanning Electron Microscope (SEM) and imaged in Zeiss Sigma VP microscope under full vacuum at the Laboratório de Microanálises of the Universidade Federal do Pará (IG - UFPA). It was not necessary to critical-point dry them. The trichomes were described according to Theobald et al. (1979). The images were falsely colored using Photoshop CS4 (Adobe).

Sampling, DNA Extraction, PCR Amplification, Sequencing and Phylogenetic analysis. For this study, the subfamilies Bombacoideae, Brownlowioideae, Byttnerioideae, Dombeyoideae, Grewioideae, Helicterioideae, Malvoideae and Sterculioideae are represented by sequences published by Hernández-Gutiérrez \& Magallón (2019). Christiana mennegae was newly sequenced for this study and included in the aligned matrix (Zappi et al. 4562 - MG). The outgroup included species of Bixaceae, Cistaceae, Neuradaceae and Thymelaeaceae. 
We reconstructed a Malvaceae s.l. phylogenetic tree in order to infer the placement of

127 Christiana mennegae using five molecular regions, four from the plastid genome $(r b c \mathrm{~L}, a t p \mathrm{~B}$,

128

129

130

131

132

133

134

135

136

137

138

139

140

141

142

143

144

145

146

147

148

149

150

151

152

153

154

155

$\operatorname{trnK}-m a t \mathrm{~K}, n d h \mathrm{~F})$, and the nuclear ITS2 from the 35S rRNA. For $C$. mennegae, sequences of ITS2 and $r b c \mathrm{~L}$ were newly obtained and deposited in the GenBank database under the accession numbers MT741784 and MT742086, respectively. For a detailed description of automated DNA extraction protocol see electronic supplementary material.

The alignment of Christiana mennegae DNA sequences was performed manually in the aligned matrix by Hernández-Gutiérrez \& Magallón (2019). Bayesian Inference (BI) and Maximum Likelihood (ML) methods were used for the phylogenetic reconstruction. Partitioned BI analyses were performed using MrBayes version 3.2.3 (Ronquist et al., 2012), with DNA substitution models selected by Hernández-Gutiérrez \& Magallón (2019) (GTR + I + G). Further details on phylogenetic analysis can be also found in electronic supplementary material.

\section{Results}

\section{Taxonomic treatment}

Christiana mennegae (Jans.-Jac. \& Westra) Kubitzki, Bot. Jahrb. Syst. 116 (4): 541. 1995. $\equiv$ Asterophorum mennegae Jans.-Jac. \& Westra, Proc. Kon. Ned. Akad. Wetensch, B 86(3): 377. 1983.

Type. Suriname, [Sipaliwini], "Morro Grande" camp-forest island, $6 \mathrm{~km} \mathrm{~W}$ of "Morro Grande" dome, Sipaliwini savanna area on the Brazilian frontier, 04 nov 1968 (lf, fl, fr), F.H.F. Oldenburger, R. Norde \& J.P. Schulz ON415 (second-step lectotype, designated here: U [U0006902; digital image!], isolectotype: K [K000381142; digital image!], MO [not seen], NY [NY00415374; digital image!], P [P02143012; digital image!], U [U0006903; digital image!], VEN [VEN409940; digital image!]). (Figs. 1,2,3,4 and 5).

Description. Trees 5-17 m tall, functionally dioecious; external bark in male plants shedding as thin scales, female plants with conspicuous and raised lenticels. Branches cylindrical, lenticellate, with sparse stellate trichomes. Stipules 2.8-3.8 mm long, linear, apex acute, with stellate trichomes. Leaves alternate, spirally arranged; petioles $1.8-5.6 \mathrm{~cm}$ long, with scattered minute stellate, sessile trichomes; leaf-blades chartaceous, 12.3-22(-29) $\times 5-8(-9) \mathrm{cm}$, narrowly elliptic, lanceolate or oblanceolate, apex long acuminate, caudate or cuspidate, base rounded to obtuse,

Peer) reviewing PDF | (2020:07:50794:3:0:NEW 22 Jul 2021) 
156 rarely slightly subcordate, margin entire or rarely slightly erose, adaxial surface shiny when dried, 157 glabrescent except for scattered stellate, sessile trichomes on the veins, abaxial surface glabrescent

158

159

160

161

162

163

164

165

166

167

168

169

170

171

172

173

174

175

176

177

178

179

180

181

182

183

184

185

186 or with scattered glandular, trichomes stellate on the veins; venation eucamptodromous, 5-6 pairs of secondary veins, veins abruptly spaced out distally. Inflorescence axillary, congested or laxa, 3.6-4(-5.5) cm long, 3-8-flowered cymes; stellate trichomes, bracts 3-1.2 mm long, triangular, with lateral linear projections, stellate trichomes on both surfaces, bracteoles $2-2.7 \times 0.3-4 \mathrm{~mm}$, entire, linear, stellate trichomes. Flowers functionally unisexual, pedicellate; calyx gamossepalous, fused by $2 \mathrm{~mm}$ long, with free lobes, externally green, with stellate trichomes, internally glabrous, subglobose to campanulate; corolla dialypetalous, white, petals obovate to oblanceolate or elliptic, glabrous on both surfaces. Staminate flowers: pedicels 2.5-4 mm long; flowers ca. $8 \mathrm{~mm}$ long;; calyx (3-)4-merous, c. $2.2 \times 3 \mathrm{~mm}$; corolla 5-7-merous, petals 5.5-7 × 1.8-3.5 mm; stamens 6367 , the inner ones longer than the outer ones, glabrous, filaments $2.5-3 \mathrm{~mm}$ long, connate by c. 1 $\mathrm{mm}$ long, anthers $0.5-0.8 \mathrm{~mm}$ long. Pistillate flowers: pedicels c. $4 \mathrm{~mm}$ long; flowers c. $6(-7) \mathrm{mm}$ long; calyx (3-)4-5-merous, 1.5-2.8 × 1.5-2(-4) mm; corolla 5-7-merous, petals 5-7.5 × 2-2.8 mm; staminodes 2-2.7 mm long, anthers c. $0.3 \mathrm{~mm}$ long; gynoecium c. $4.2 \mathrm{~mm}$ long, ovary c. $2 \times$ $2 \mathrm{~mm}$, trichomes stellate, style c. $1.8 \mathrm{~mm}$ long, trichomes stellate, stigma 5, c. $0.6 \mathrm{~mm}$ long, ovules c. $0.5 \mathrm{~mm}$ long. Fruit capsule, woody, syncarpous, $1.2-1.8 \mathrm{~cm}$ long, c. $3.8 \mathrm{~cm}$ diam., depressedglobose, externally with stellate trichomes, composed of 5 loculicidal, one-seeded per locule; seed obovate, 8-9 × 6-7 mm, glabrous, medium brown with darker irregular marks.

Nomenclatural notes: Christiana mennegae was described from a single collection deposited at $\mathrm{U}$, Oldenburger ON415. However, there are two separate sheets from this collection in the same herbarium. Jansen-Jacobs \& Westra (1983) did not specify which sheet should be the type, and although they published photos, they use images of the two materials, considering both as the holotype. Therefore, it is necessary to do the second step of lectotypification and we selected specimen U0006902 because it is more complete than the other sheets.

Distribution and habitat: Christiana mennegae was first known from Suriname, Brazil (JansenJacobs \& Westra, 1983; Kubitzki, 1995; Secco, 2000) and here we record it for the first time in Peru. This new record is a significant extension of its range, nearly $1,700 \mathrm{~km}$ from the nearest recorded occurrence of the species (Fig. 1). This species can be found growing in island of evergreen seasonal forest in savannas in Suriname and in rainforest at up to $600 \mathrm{~m}$ elevation in Brazil. In Peru, C. mennegae grows in wet forest in the central region, from 500 to $600 \mathrm{~m}$ elevation. 
187 According to Cruz \& Taylor (2018), the central region of Peru has a complex geology and its 188 botany is yet little explored. The specimens listed by Secco (2000), deposited in IAN herbarium, 189 unfortunately could not be found.

190 Phenology: The species apparently flowers at the onset of the wet season and has been collected 191 with flowers and fruits in September, November and January and only fruiting in July.

192 Comments: Christiana mennegae shares syncarpic fruits with the Neotropical species C. eburnea 193 (Sprague) Kubitzki and C. macrodon Toledo. A complete morphological comparison between the 194 species of Christiana is found in a table in the electronic supplementary material. These species 195 196 are distinguished by their narrowly elliptic, lanceolate or oblanceolate leaf-blades ( $v s$. ovate or widely ovate to circular) with rounded to obtuse or rarely subcordate base (vs. truncate to subcordate or cordate). Cristiana mennegae also differs from C. eburnea by depressed-globose fruits (vs. subturbinate to turbinate) and from C. macrodon by leaf-blades with entire or rarely slightly erose margins (vs. sparsely dentate). From C. africana, the most widespread species of the genus (Kubitzki, 1995), C. mennegae can be easily distinguished by the leaf-blades narrowly elliptic, lanceolate or oblanceolate with rounded to obtuse base ( $v s$. widely ovate with cordate base) and fruits syncarpic (vs. apocarpic) (Fig. 2). In addition, according to the results here obtained, $C$. mennegae is reported so far as the only species of the genus to present glandular trichomes on the leaf-blades, a character that distinguishes it from the other four species. The presence of up to seven petals in $C$. mennegae was not recorded until the present analysis. There were differences in appearance of the external bark between male and female individuals (Fig. 5 A-B). A total of three new physical specimens and ten digitally imaged specimens were located.

Besides the morphological characters mentioned, Christiana mennegae can be separated geographically from the other species. While C. mennegae is currently known from Suriname, northern Brazil (Amazonas and Pará states) and Peru, C. eburnea is known only from the type locality in Ecuador, and C. macrodon only from Southeastern Brazil (São Paulo state) (Sprague, 1908; Toledo, 1952; Kubitzki, 1995). Christiana africana occurrs in Africa, Mexico, Central and South America (Brazil, Ecuador, Guianas and Venezuela) and Madagascar (Kubitzki, 1995; Tschá et al., 2002; Door et al., 2007), however no records of sympatry between it and C. mennegae have been found thus far.

Conservation status: The last update of Christiana mennegae took place in 1998 and classified the species as vulnerable (World Conservation Monitoring Centre. 2017). The present data shows 
218 that Christiana mennegae occurs in two protected areas in Brazil, in the Parque Estadual da Serra

219 do Aracá in the state of Amazonas and in the Floresta Nacional de Carajás in the state of Pará. In

220 addition to those, it occurs in the forest islands in savanna of the Sipaliwini Savanna Nature

221 Reserve in Suriname. Despite appearing to be locally rare, C. mennegae is known from four

222 localities spread throughout the Amazon basin, with a EOO of more than 1,000,000 $\mathrm{km}^{2}$ fitting

223 within the Least Concern (LC) category of IUCN (2012). Unfortunately it was not possible to

224 estimate the size of the populations. Therefore we suggest a revision of its category of threat.

225 Specimens examined: BRAZIL. Amazonas: margem de um igarapé que nasce na Serra de Aracá, 226 28/07/1977, fr., N.A. Rosa \& M.R. Cordeiro 1699 (RB00059283 [digital image]). Pará: Marabá, 227 [Mun. Parauapebas], Serra dos Carajás, 29/11/1988, fr., N.A. Rosa \& F.C. Nascimento 5084 228 (K001214118 [digital image]); Mun. Parauapebas, FLONA de Carajás, imediações do Parque 229 Zoobotânico, fl./fr., 06/09/2018, D.C. Zappi et al. 4562 (MG); Parque Zoobotânico, fl, 05/10/2019, 230 R.G. Barbosa-Silva et al. 1424 (MG); Nova-Canaã dos Carajás [Canaã dos Carajás], 06/01/2001, 231 fl/fr., L.C.B. Lobato 2624 (MG163877); PERU. San Martin: Mariscal Cáceres, Tocache Nuevo, 232 15/11/1972, fr., J. Schunke Vigo 5516 (F1780039 [digital image], MO, NY).

233

\section{Micromorphology study}

The five types of sessile trichomes observed in Christiana mennegae can be grouped under non-glandular and glandular types. There are four types of non-glandular trichomes, which can be either classed as unbranched (simple and two-armed trichomes) or fall into two different branched categories (stellate-rotate and stellate-multiangulate trichomes). A detailed description of nonglandular trichomes can be found in electronic supplementary material, micromorphology study.

The endocarp of the fruit is smooth and lacked stomata (Fig. 3 E). Stomata were observed on the seed surfaces, evenly throughout the surface (Fig. $3 \mathrm{G}-\mathrm{H}$ ) and were sparsely distributed in the analyzed material.

\section{Phylogenetic relationships}

The tree topology with combined dataset (nuclear and plastid) in both analyses showed that Christiana mennegae emerged in a clade with C. africana, although only the ML analysis resulted in a highly supported monophyletic branch $(\mathrm{BS}=86 ; \mathrm{PP}=0.78)($ Fig. 4). As there are sequences 
248 available only for these two species of the genus, we could not reach any further conclusions on

249 the relationships within Christiana. In addition, our results revealed Christiana in a strongly 250 supported clade including the sampled species of Berrya and Cardioptera $(\mathrm{BS}=78 ; \mathrm{PP}=1)$, 251 although with no clear relationship patterns among the genera (Fig. 4). Both analyses recovered 252 the same supported clades (see ML tree in electronic supplementary material).

253

254

\section{Discussion}

Jansen-Jacobs \& Westra (1983) described Asterophorum mennegae Jansen-Jacobs \& Westra based on Oldenburger et al. 415 from Suriname. Later, Kubitzki (1995) expanded the circumscription of Christiana to include the genera Asterophorum (2 spp.) and Tahitia (1 sp.). Kubitzki (1995) recorded the occurrence of A. mennegae in Brazil for the first time. Although Kubitzki mentioned some vouchers from Amazonas and Pará states, the specimens have not been properly identified in herbarium collections and were overlooked by Secco (2000), who reported the occurrence of Asterophorum mennegae as the first record of the species for the Brazilian Amazon; nevertheless, this publication was overlooked by subsequent authors. Kubitzki's (1995) work is not easily accessible in Brazil and has not yet been made available in online libraries, and this could explain why Secco (2000) did not use Kubitzki's (1995) circumscription. Secco (2000) is not available in online repositories either. Coutinho (2020) used online databases such as SpeciesLink and JABOT (http://rb.jbrj.gov.br/v2/consulta.php) and recorded only C. africana and C. macrodon in the Brazilian Flora 2020 (Flora do Brasil 2020). In addition, the difficulty accessing Kubitzki (1995) and Secco (2000) may have contributed to the deficient knowledge of Christiana until the present moment. The case of $C$. mennegae is an example of overlooked taxa and also highlights the collecting gaps in the Amazon. Similar floristic projects also reported dozens of new records and also overlooked species in the Amazon (Barbosa-Silva et al., 2016, Sierra et al., 2019).

Stomata on seed surfaces are relatively uncommon (Paivaet al., 2006), although recorded for several unrelated plant families (Jernstedt \& Clark, 1979), and the presence of such structures in C. mennegae is the first report for the Brownlowioideae. On the other hand, the presence of stomata in Malvaceae seeds has been reported in other subfamilies, such as Sterculioideae, Bombacoideae and Malvoideae (Corner, 1976). The morphological variation on seed surface and indumentum in other groups of Brownlowioideae has already shown to be of taxonomic 
279 importance, such as presence of trichomes on the seeds in Jarandersonia (Chung et al., 2012).

280 Besides being a stable character, the presence of stomata in seeds may contribute to the taxonomy 281 of the group, and was used in conjunction with other seed surface characters to recognize a new 282 taxon in Jarandersonia from Borneo (Tan et al., 2011). However, there is an example in the genus 283 Iris L. (Iridaceae) in which the occurrence of seed stomata was not a useful taxonomic character 284 (Wang \& Hasenstein, 2016).

285 Five trichome types were found in Christiana mennegae and among them, the glandular 286 trichomes on the abaxial surface of the leaf-blades, were also seen in species of Luehea Willd., 287 Lueheopsis Burret, Vasivaea Baill., Triumfetta L. and Mollia Mart. (Malvaceae-Grewioideae), as 288 well as in Heliocarpus popayenensis H.B.K. (Malvaceae-Grewioideae) and Christiana africana 289 (Westra, 1967), where the indument beneath the leaves is markedly different in comparison with 290 that of the petioles and branches, as related here for C. mennegae. Westra (1967) performed a 291 broad micromorphological study in Apeiba and provided valuable data about distribution and 292 trichome types for that genus. Tan et al. (2011) and Chung et al. (2012) used the trichome type on 293 the leaf, fruit and seed, associated to other characters to distinguish between species of 294 Jarandersonia (Malvaceae-Brownlowioideae). Nurhanim et al. (2010) studied the trichomes diversity in 18 species of Pentace Hassk. (Malvaceae-Brownlowioideae) and demonstrated the systematic taxonomic value of 15 trichome types found.

Ultimately, it was not possible to confirm the monophyly of Christiana due to the low sampling of taxa and conflicting statistical support obtained $(\mathrm{BS}=86 ; \mathrm{PP}=0.78)$. On the other hand, our data supported the inclusion of Christiana, Carpodiptera and Berrya, which present fused calyx-lobes (Whitehouse et al., 2001), in a strongly supported clade, as previously indicated by Alverson et al. (1999), Bayer et al. (1999), Richardson et al. (2015) and Hernández-Gutiérrez \& Magallón (2019). Although a close relationship between Christiana and Carpodiptera is reasonable, as they are the only Brownlowioideae genera with unisexual flowers (Bayer \& Kubitzki, 2003), increasing both the sampled species and the number of DNA regions is crucial to clarify the relationships within this clade.

The availability of morphological and molecular data helps to accelerate the delimitation and identification of species (Ramalho et al., 2018), thus allowing to rapidly quantify plant 308 diversity in the Amazon. Other Amazonian species may prove to have similar wide range expansions when more collecting effort is employed in remote areas, more investment in training 
310 botanists (Ahrends et al., 2010), more herbarium collections are digitized and published online,

311 and missing literature is eventually made available electronically.

312

\section{Conclusions}

314

315

316

317

318

319

320

321

322

323

324

325

326

327

328

329

330

331

The example of Christiana mennegae highlights the need for continuous investment in the digitization of biological collections, investment in local capacity building for botanists and the availability of online literature for the study of Amazonian biodiversity. The new occurrences recorded here include samples collected many years ago but that were either overlooked or not identified, and therefore an already accepted species had escaped the radar of the Brazilian Flora until now. Our intention was to improve the knowledge to raise the profile of $C$. mennegae by adding data of its micromorphology and a preliminary phylogenetic perspective. It is possible that the discovery of the stomata in the seed surface in this subfamily may be interesting to contribute towards the elucidation of the evolution of morphology in Malvaceae.

\section{Acknowledgements}

The authors thank, Ana Correa from Laboratório de Microanálises do Instituto de Geociências (IG) in UFPA for the help in taking SEM images. To João Silveira, who prepared the line drawing. To Caroline Oliveira Andrino for helping in phylogenetic analyses and comments on an early version of the paper. To Raquel Negrão for comments regarding conservation status. To the Curators of the collections studied, especially Helena J. R. Souza (IAN), Pedro L. Viana (MG) and Lourival Tyski (HCJS). 
332

333

334

335

336

337

338

339

340

341

342

343

344

345

346

347

348

349

350

351

352

353

354

355

\section{References}

Ahrends A, Rahbek C, Bulling MT, Burgess ND, Platts PJ, Lovett JC, Kindemba VW, Owen N, Sallu AN, Marshall AR, Mhoro BE, Fanning E, Marchant R. 2011. Conservation and the botanist effect. Biological Conservation 144:131-140. DOI: 10.1016/j.biocon.2010.08.008.

Alverson WS, Whitlock BA, Nyffeler R, Bayer C, Baum DA. 1999. Phylogeny of the core Malvales: evidence from ndhF sequence data. American Journal of Botany 86:1474-1486. DOI: $10.2307 / 2656928$.

Bachman S, Moat J, Hill A, de la Torre J, Scott B. 2011. Supporting Red List threat assessments with GeoCAT: geospatial conservation assessment tool. ZooKeys 150:117-126. DOI: 10.3897/zookeys.150.2109.

Barbosa-Silva RG, Labiak PH, Dos Santos Bragança Gil A, Goldenberg R, Michelangeli FA, Martinelli G, Nadruz Coelho MA, Zappi DC, Forzza RC. 2016. Over the hills and far away: New plant records for the Guayana Shield in Brazil. Brittonia 68:397-408. DOI: 10.1007/s12228-016-9435-3.Bayer C, Fay MF, Bruijn AY, Savolainen V, Morton CM, Kubitzki K, Alverson WS, Chase MW. 1999. Support for an expanded family concept of Malvaceae within a recircumscribed order Malvales: a combined analysis of plastid atpB and rbcL DNA sequences. Botanical Journal of the Linnean Society 129:267-303. DOI: 10.1111/j.1095-8339.1999.tb00505.x.

Bayer C, Fay MF, Bruijn AY, Savolainen V, Morton CM, Kubitzki K, Alverson WS, Chase MW. 1999. Support for an expanded family concept of Malvaceae within a recircumscribed order Malvales: a combined analysis of plastid atpB and rbcL DNA sequences. Botanical Journal of the Linnean Society 129:267-303. DOI: 10.1111/j.10958339.1999.tb00505.x. 
356

357

358

Bayer C, Kubitzki K. 2003. Malvaceae. In: Flowering Plants, Dicotyledons: Malvales, Capparales and Non-betalain Caryophyllales. 225-311.

BFG. 2018. Brazilian Flora 2020: Innovation and collaboration to meet Target 1 of the Global Strategy for Plant Conservation (GSPC). Rodriguésia 69:1513-1527. DOI: $10.1590 / 2175-7860201869402$.

Black GA, Dobzhansky T, Pavan C. 1950. Some attempts to estimate species diversity and population density of trees in Amazonian Forests. Botanical Gazette 111:413-425.

Brazil Flora Group [BFG]. 2015. Growing knowledge: an overview of Seed Plant diversity in Brazil. Rodriguésia 66:1085-1113. DOI: DOI: 10.1590/2175-7860201566411.

Canhos DAL, Sousa-Baena MS, Souza S, Garcia LC, De Giovanni R, Maia LC, Bonacelli MBM. 2014. Lacunas: a web interface to identify plant knowledge gaps to support informed decision-making. Biodiversity and Conservation 23:109-131. DOI: 10.1007/s10531-013-0587-0.

Cardoso DBOS, Carvalho-Sobrinho JG, Zartman CE, Komura DL, Queiroz LP. 2015. Unexplored Amazonian diversity: rare and phylogenetically enigmatic tree species are newly collected. Neodiversity 8:55-73. DOI: 10.13102/neod.81.4.

Cardoso D, Särkinen T, Alexander S, Amorim AM, Bittrich V, Celis M, Daly DC, Fiaschi P, Funk VA, Giacomin LL, Goldenberg R, Heiden G, Iganci J, Kelloff CL, Knapp S, Lima HC de, Machado AFP, Santos RM dos, Mello-Silva R, Michelangeli FA, Mitchell J, Moonlight P, Moraes PLR de, Mori SA, Nunes TS, Pennington TD, Pirani JR, Prance GT, Queiroz LP de, Rapini A, Riina R, Rincon CAV, Roque N, Shimizu G, Sobral M, Stehmann JR, Stevens WD, Taylor CM, Trovó M, Berg C van den, Werff H van der, Viana PL, Zartman CE, Forzza RC. 2017. Amazon plant diversity revealed by a 
taxonomically verified species list. Proceedings of the National Academy of Sciences 114:10695-10700. DOI: 10.1073/pnas.1706756114.

Chung RCK, Tan HS, Soepadmo E. 2012. A remarkable new species of Jarandersonia (Malvaceae-Brownlowioideae) from Central Kalimantan, Borneo. Systematic Botany 37:213-217. DOI: 10.1600/036364412X616774.

Corner EJH. 1976. The seeds of dicotyledons. ambridge: Cambridge University Press.

Coutinho TS. Christiana in Flora do Brasil 2020 em construção. Jardim Botânico do Rio de Janeiro.Disponível em: <http://reflora.jbrj.gov.br/reflora/floradobrasil/FB85>. Accessed: 01 jan. 2021

Cruz MC, Taylor CM. 2018. Two New Species of Hippotis (Rubiaceae) from Ecuador and Peru. Novon: A Journal for Botanical Nomenclature 26:143-149. DOI: 10.3417/2018062.

De Candolle AP. 1824. Prodromus systematis naturalis regni vegetabilis.Vol. 1. Paris: Treuttel and Würtz.

Door LJ, Jansen-Jacobs MJ, Meijer W. 2007. Tiliaceae. In: Checklist of the Plants of the Guiana Shield (VENEZUELA: Amazonas, Bolivar, Delta Amacuro; GUYANA, SURINAM, FRENCH GUIANA). Smithsonian Institution: Contributions from United States national Herbarium, 585.

Ebach MC, Valdecasas AG, Wheeler QD. 2011. Impediments to taxonomy and users of taxonomy: accessibility and impact evaluation. Cladistics 27:550-557. DOI: 10.1111/j.1096-0031.2011.00348.x.

Flora do Brasil. under construction.Flora do Brasil online 2020, Jardim Botânico do Rio de Janeiro. Available at 
401

402

403

404

405

406

407

408

409

410

411

412

413

414

415

416

417

418

419

420

421

422

423

http://floradobrasil.jbrj.gov.br/reflora/listaBrasil/ConsultaPublicaUC/ResultadoDaCons

ultaNovaConsulta.do\#CondicaoTaxonCP (accessed March 8, 2018).

Ferreira AR, Soares PM, Ferrão C, Landi AJ. 2008. Viagem ao Brasil de Alexandre Rodrigues

Ferreira : a expedição philosophica pelas Capitanias do Pará, Rio Negro, Mato Grosso

e Cuyabá. Petrópolis: Kapa Editorial.

Forzza RC, Baumgratz JFA, Bicudo CEM, Canhos DAL, Carvalho AA, Coelho MAN, Costa AF, Costa DP, Hopkins MG, Leitman PM, Lohmann LG, Lughadha EN, Maia LC,

Martinelli G, Menezes M, Morim MP, Peixoto AL, Pirani JR, Prado J, Queiroz LP, Souza S, Souza VC, Stehmann JR, Sylvestre LS, Walter BMT, Zappi DC. 2012. New

Brazilian Floristic List Highlights Conservation Challenges. BioScience 62:39-45. DOI: 10.1525/bio.2012.62.1.8.

Forzza RC, Baumgratz JFA, Bicudo CEM, Carvalho AA, Costa A, Costa DP, Hopkins M, Leitman P, Lohmann LG, Maia LC, Martinelli G, Menezes M, Morim MP, Coelho MAN, Peixoto AL, Pirani JR, Prado J, Queiroz LP, Souza VC, Stehmann JR, Sylvestre LS, Walter BMT, Zappi D. 2010. Catálogo de plantas e fungos do Brasil. Rio de Janeiro: Jardim Botânico do Rio de Janeiro.

Funk VA. 2018. Collections-based science in the 21st Century: Collections-based science in the 21st Century. Journal of Systematics and Evolution 56:175-193. DOI: $10.1111 /$ jse. 12315 .

Gentry AH. 1988. Tree species richness of upper Amazonian forests. Proceedings of the National Academy of Sciences 85:156-159. DOI: 10.1073/pnas.85.1.156.

Gwinn NE, Rinaldo C. 2009. The Biodiversity Heritage Library: sharing biodiversity literature with the world. IFLA Journal 35:25-34. DOI: 10.1177/0340035208102032. 
424 Harris J, Harris MW. 2001. Plant identification terminology: an illustrated glossary. Utah:

$425 \quad$ Spring Lake Publishing.

426 Hemming J. 2015. Naturalists in Paradise Wallace, Bates and Spruce in the Amazon. London:

427 Thames \& Hudson.

428 Hernández-Gutiérrez R, Magallón S. 2019. The timing of Malvales evolution: Incorporating its 429 extensive fossil record to inform about lineage diversification. Molecular Phylogenetics $430 \quad$ and Evolution 140:106606. DOI: 10.1016/j.ympev.2019.106606.

431 Hopkins MJG. 2019. Are we close to knowing the plant diversity of the Amazon? Anais da 432 Academia Brasileira de Ciências 91. DOI: 10.1590/0001-3765201920190396.

433

434

435

436

437

438

439

440

441

442

443

444

445

446

Hubbell SP, He F, Condit R, Borda-de-Agua L, Kellner J, ter Steege H. 2008. How many tree species are there in the Amazon and how many of them will go extinct? Proceedings of the National Academy of Sciences 105:11498-11504. DOI: 10.1073/pnas.0801915105.

IUCN. 2012. IUCN Red List categories and criteria. Gland.

Jansen-Jacobs MJ., Westra LYT. 1983. Studies on the flora of the Guianas. II. A new species of Asterophorum (Tiliaceae) from Suriname. :377-383.

Jernstedt JA, Clark C. 1979. Stomata on the Fruits and Seeds of Eschscholzia (Papaveraceae). American Journal of Botany 66:586. DOI: 10.2307/2442508.

Kubitzki K. 1995. Asterophorum and Tahitia congeneric with Christiana (Tiliaceae).

Bot. Jahrb. Syst. 116(4): 537-542.

La Condamine C-M de, Godin des Odonais J. 1808. Abridged narrative of travels through the interior of South America from the shores of the Pacific Ocean to the coasts of Brazil and Guyana, descending the river of Amazons; A general collection of the best and most interesting voyages and travels ... 14 . 
447 Milliken W, Zappi D, Sasaki D, Hopkins M, Pennington RT. 2010. Amazon vegetation: how 448 much don't we know and how much does it matter? Kew Bulletin 65:691-709.

449 Morim MP, Lughadha EMN. 2015. Flora of Brazil Online: can Brazil's botanists achieve their 4502020 vision? Rodriguésia 66:1115-1135. DOI: 10.1590/2175-7860201566412.

451 Nyffeler R, Bayer C, Alverson WD, Yen A, Whitlock BA, Chase MW, Baum DA. 2005.

452 Phylogenetic analysis of the Malvadendrina clade (Malvaceae s.1.) basedon plastid DNA 453 sequences. Organisms, Diversity \& Evolution 5: 109-123.

454 Nurhanim MN, Noraini T, Chung RCK. 2010. The systematic significance of trichome types in 455 Pentace Hassk. (Tiliaceae). Malaysian Journal of Microscopy 6:19-22.

456 Paiva ÉAS, Lemos-Filho JP, Oliveira DMT. 2006. Imbibition of Swietenia macrophylla

457 (Meliaceae) Seeds: the role of stomata. Annals of Botany 98:213-217. DOI:

458 10.1093/aob/mcl090.

459

460

461

462

463

464

465

466

467

468

Piontekowski VJ, Ribeiro FP, Matricardi EAT, Junior IML, Bussinguer AP, Gatto A. 2019. Modeling Deforestation in the State of Rondônia. Floresta e Ambiente 26. DOI: 10.1590/2179-8087.044118.

Pires JM, Dobzhansky T, Black GA. 1953. An estimate of the number of species of trees in an amazonian forest community. Botanical Gazette 114:467-477.

QGIS Development Team J. 2016. QGIS Geographic Information System.

Radford E, Dickison WC, Massey JR, Bell CR. 1974. Vascular plant systematics. New York: Harper and Row.

Ramalho AJ, Zappi DC, Nunes GL, Watanabe MTC, Vasconcelos S, Dias MC, Jaffé R, Prous X, Giannini TC, Oliveira G, Giulietti AM. 2018. Blind testing: DNA barcoding sheds light 
469

470

471

472

473

474

475

476

477

478

479

480

481

482

483

484

485

486

487

488

489

490

491

upon the identity of plant fragments as a subsidy for cave conservation. Frontiers in Plant Science doi: 10.3389/fpls.2018.01052:1-10. DOI: doi: 10.3389/fpls.2018.01052.

REFLORA 2020. 2020.Reflora - Virtual Herbarium. Available at http://reflora.jbrj.gov.br/reflora/herbarioVirtual/(accessed July 1, 2020).

Richardson JE, Whitlock BA, Meerow AW, Madriñán S. 2015. The age of chocolate: a diversification history of Theobroma and Malvaceae. Frontiers in Ecology and Evolution 3. DOI: $10.3389 /$ fevo.2015.00120.

Ronquist F, Teslenko M, van der Mark P, Ayres DL, Darling A, Höhna S, Larget B, Liu L, Suchard MA, Huelsenbeck JP. 2012. MrBayes 3.2: efficient Bayesian phylogenetic inference and model choice across a large model space. Systematic Biology 61:539-542. DOI: $10.1093 /$ sysbio/sys029.

Schomburgk MR, Roth WE. 2017. Richard Schomburgk's Travels in British Guiana, 18401844; Volume 1. Andesite Press.

Schonfeld RC. 2003. JSTOR: A History. Princeton, NJ: Princeton University Press.

Secco RS. 2000. Asterophorum Sprague (Tiliaceae) uma nova ocorrência para a Amazônia brasileira. Boletim do Museu Paraense Emilio Goeldi. Serie Botânica 16:211-221.

Sierra AM, Pereira MR, Zartman CE. 2019. New records for the bryophyte flora of the Brazilian Amazon. Rodriguésia 70:e00192017. DOI: 10.1590/2175-7860201970013.

Spix JB von, Martius CFP von. 2013. Travels in Brazil, in the years 1817-1820: undertaken by command of His Majesty the King of Bavaria. Cambridge University Press.

Sprague TA. 1908. Decades Kewenses. Plantarum Novarum in Herbario Horti Regii Conservatarum. Decas L. Bulletin of Miscellaneous Information (Royal Gardens, Kew) 1908:249-255. DOI: 10.2307/4111573. 
492 Spruce R. 1908. Notes of a Botanist on the Amazon and Andes. 2 Vols. (Ed. by A. R. Wallace). 493 Macmillan, London.

494 ter Steege H, Mota de Oliveira S, Pitman NCA, Sabatier D, Antonelli A, Guevara Andino JE, 495 Aymard GA, Salomão RP. 2019. Towards a dynamic list of Amazonian tree species.

496

497

498

499

500

501

502

503

504

505

506

507

508

509

510

511

512

513

Scientific Reports 9. DOI: 10.1038/s41598-019-40101-y.

ter Steege H, Vaessen RW, Cárdenas-López D, Sabatier D, Antonelli A, de Oliveira SM, Pitman NCA, Jørgensen PM, Salomão RP. 2016. The discovery of the Amazonian tree flora with an updated checklist of all known tree taxa. Scientific Reports 6. DOI:

$10.1038 /$ srep29549.

Tan HS, Chung RCK, Soepadmo E. 2011. A synopsis of Jarandersonia (Malvaceae:

Brownlowioideae). The Gardens’ Bulletin Singapore 63:137-144.

Theobald WL, Krahulik JL, Rollins RC. 1979. Trichomes description and classification. In:

Metcalfe CR \& Chalk L. Anatomy of the dicotyledons.. Clarendon Press, Oxford: 42-53.

Thiers, B. 2020. [continuously updated]. Index herbariorum: A global directory of public herbaria and associated staff. New York, New York Botanical Garden's virtual herbarium. http://sweetgum.nybg.org/science/ih/. (accessed December 20, 2020)

Toledo JF. 1952. Notulae de aliquot plantis brasiliensibus novis vel minus cognitis. Arquivos de botânica do estado de São Paulo 3:29-30.

Tropicos MB garden. 2020.Tropicos.org. Available at http://www.tropicos.org (accessed March $1,2020)$.

Tschá M do C, Sales MF, Esteves GL. 2002. Tiliaceae Juss. no estado de Pernambuco, Brasil. Hoehnea 29:1-18.

Peer] reviewing PDF | (2020:07:50794:3:0:NEW 22 Jul 2021) 
514 Wang L, Hasenstein KH. 2016. Seed coat stomata of several Iris species. Flora 224:24-29. DOI:

$515 \quad$ 10.1016/j.flora.2016.07.002.

516 Westra LYT. 1967. The indument of Apeiba Aubl. (Tiliaceae). Acta Botanica Neerlandica

517 15:648-667. DOI: 10.1111/j.1438-8677.1966.tb00260.x.

518 Whitehouse C, Cheek M, Andrews S, Verdcourt B. 2001. Flora of Tropical East Africa-

519 Tiliaceae \& Muntingiaceae. Royal Botanic Gardens, Kew.

520 World Conservation Monitoring Centre. 2017. Christiana mennegae (amended version of 1998

521 assessment). The IUCN Red List of Threatened Species 2017:

522 e.T36194A116360017. https://dx.doi.org/10.2305/IUCN.UK.2017-

$523 \quad$ 2.RLTS.T36194A116360017.en. Downloaded on 5 January 2021.

524 
Figure 1

Distribution of Christiana mennegae based on examined material.

In the far west, the new record of $C$. mennegae in Peru.

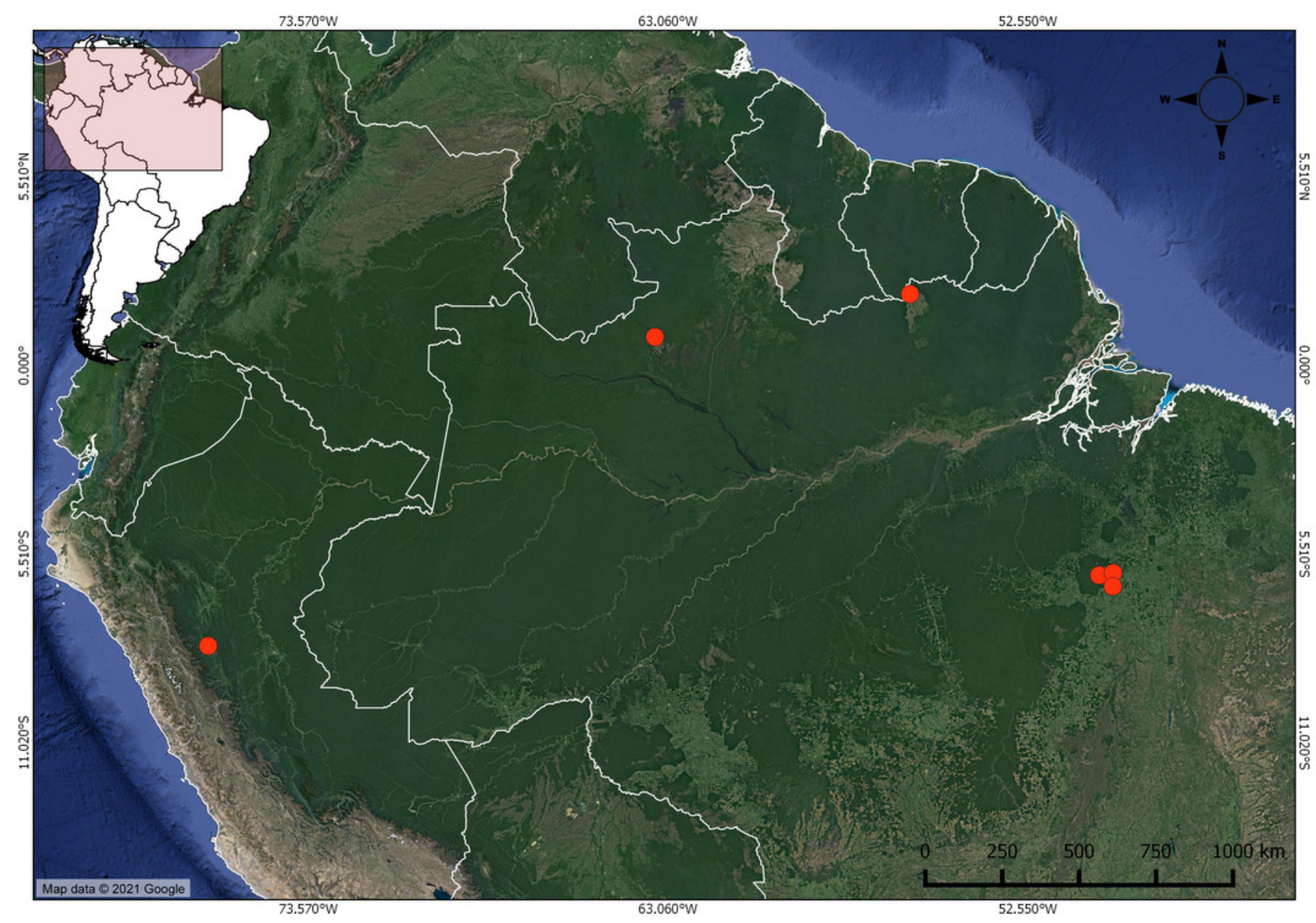




\section{Figure 2}

Christiana mennegae.

(A) Fertile branch. (B) Leaf. (C) Detail of the petiole showing stellate trichomes. (D) Detail of an inflorescence. (E) Staminate flower. (F) Detail of the stellate multi-angulate trichomes on the calyx. (G) Staminate flower with a petal removed showing the arrangement of the stamens. (H) Petal (adaxial view). (I) Anthers. (J) Pistillate flower. (K) Detail of a dissected pistillate flower with staminodes. (L) Gynoecium. (M) Fruit. (N). Side view of capsule valves. (0) Seed. A-I from Zappi et al. 4562; J-O from Barbosa-Silva et al. 1424. Drawn by João B. Silveira 


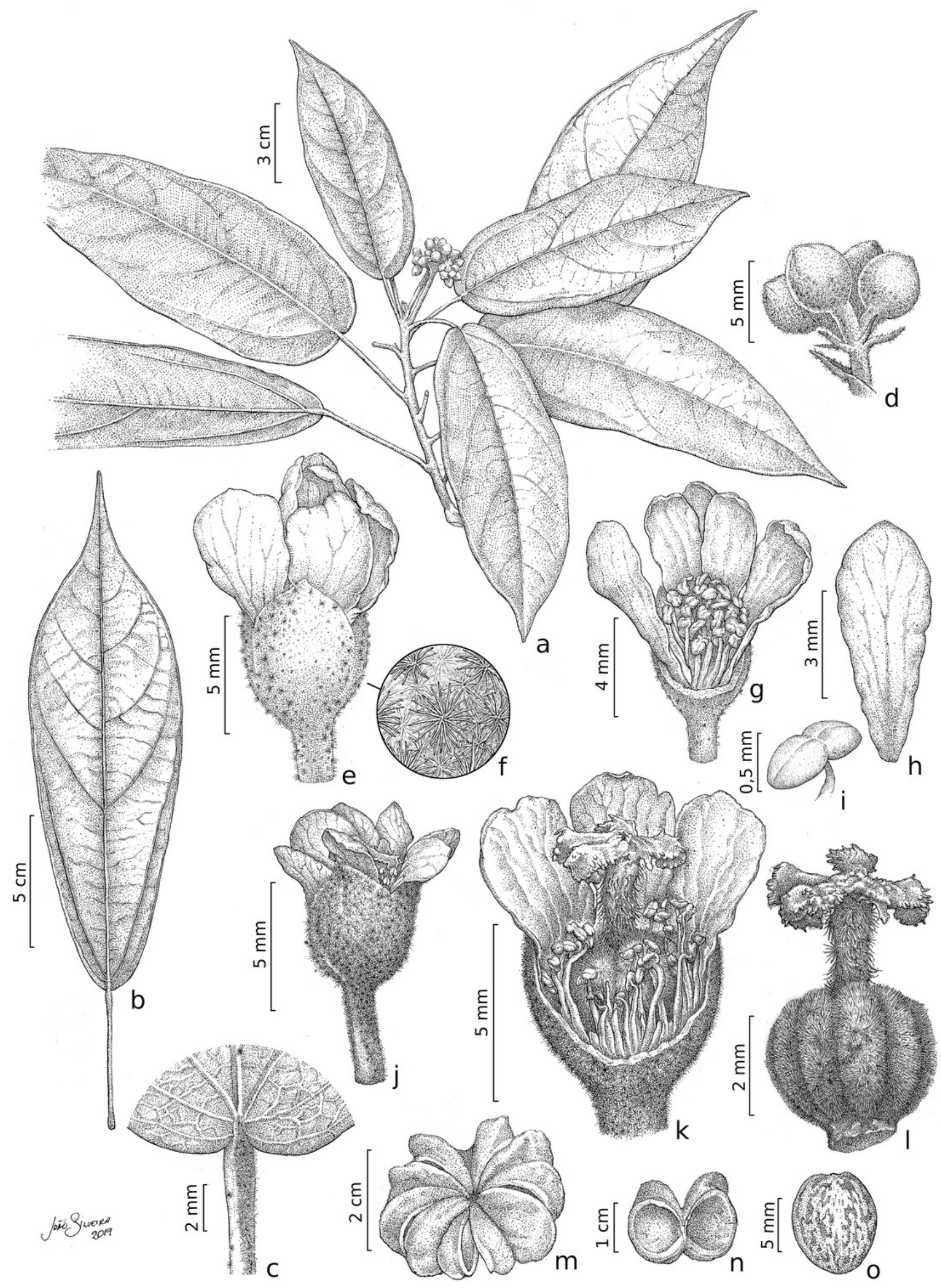




\section{Figure 3}

SEM images of the Christiana mennegae

(A) Simple trichomes (yellow), stellate-rotate trichomes (dark blue), two-armed trichomes

(pink), glandular trichomes (orange) on the petioles. (B) Glandular trichomes (orange) and stoma on abaxial surface of the blade leaf. (C) Stellate rotate trichomes (dark blue) on the veins of the abaxial surface of the blade leaf and glandular trichomes (orange) on the rest of the surface. (D) Stellate-multiangulate trichomes on external surface of the calyx. (E) Fruit showing stellate-multiangulate trichomes (light blue) on epicarp and glabrous and without stomata on endocarp (yellow). (F) Detail of concentrated stellate multiangulate trichomes (light blue) on epicarp. (G) Seed surface showing many stomata. (H) Details of stomata in seeds surface. Scale bars: A-100 $\mu \mathrm{m} ; \mathrm{B}-20 \mu \mathrm{m}$; C- $100 \mu \mathrm{m}$; D- $100 \mu \mathrm{m}$; E- 200; F- $100 \mu \mathrm{m}$;

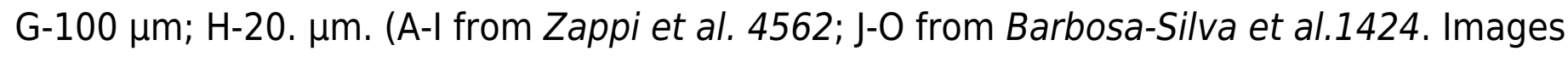
by Ana Correa. 

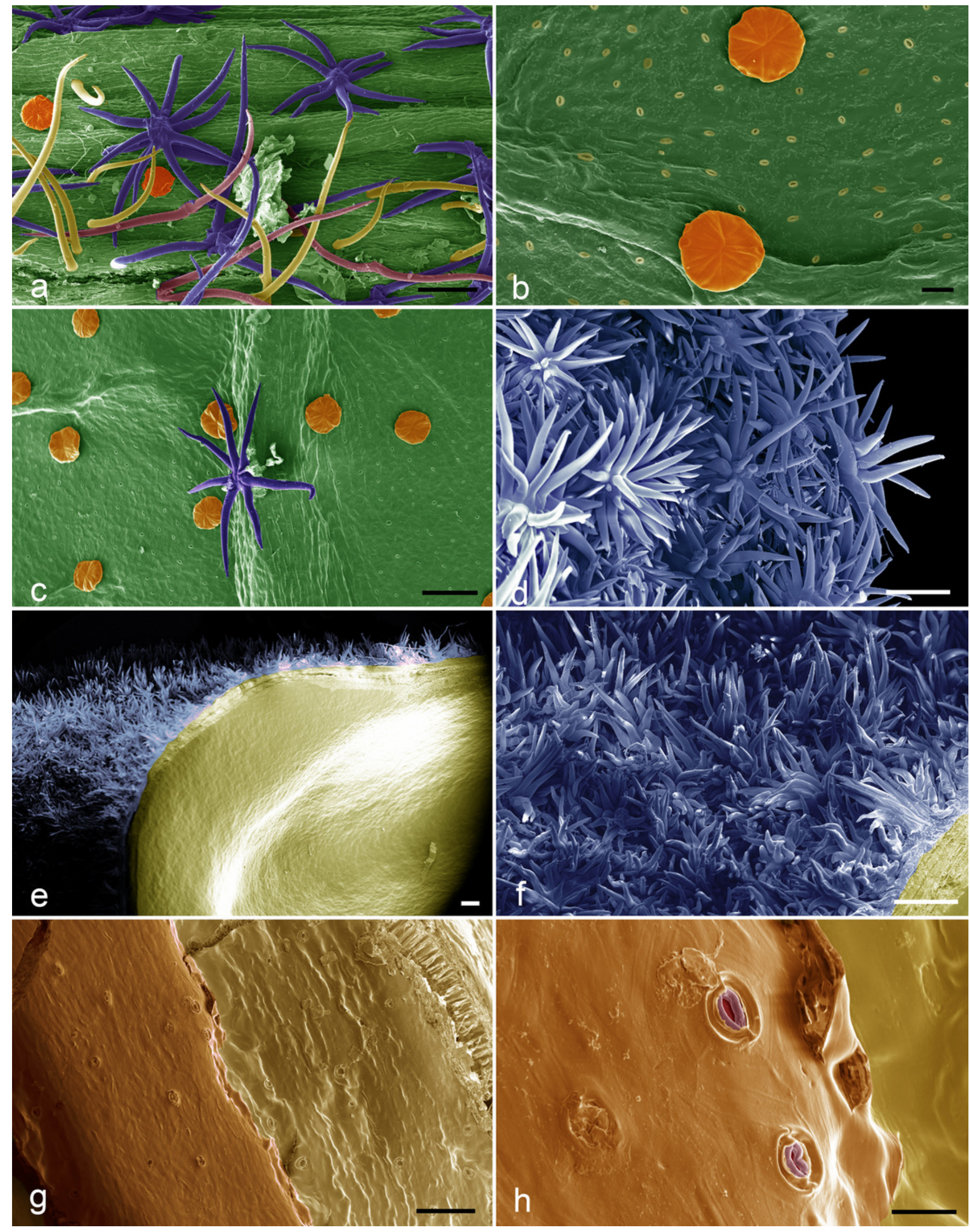
Figure 4

\section{Majority rule consensus tree of Malvales}

Emphasis on subfamily Brownlowioideae resulting from a Bayesian analysis of the combined dataset (atpB, trnK-matK, ndhF, rbcL and ITS).

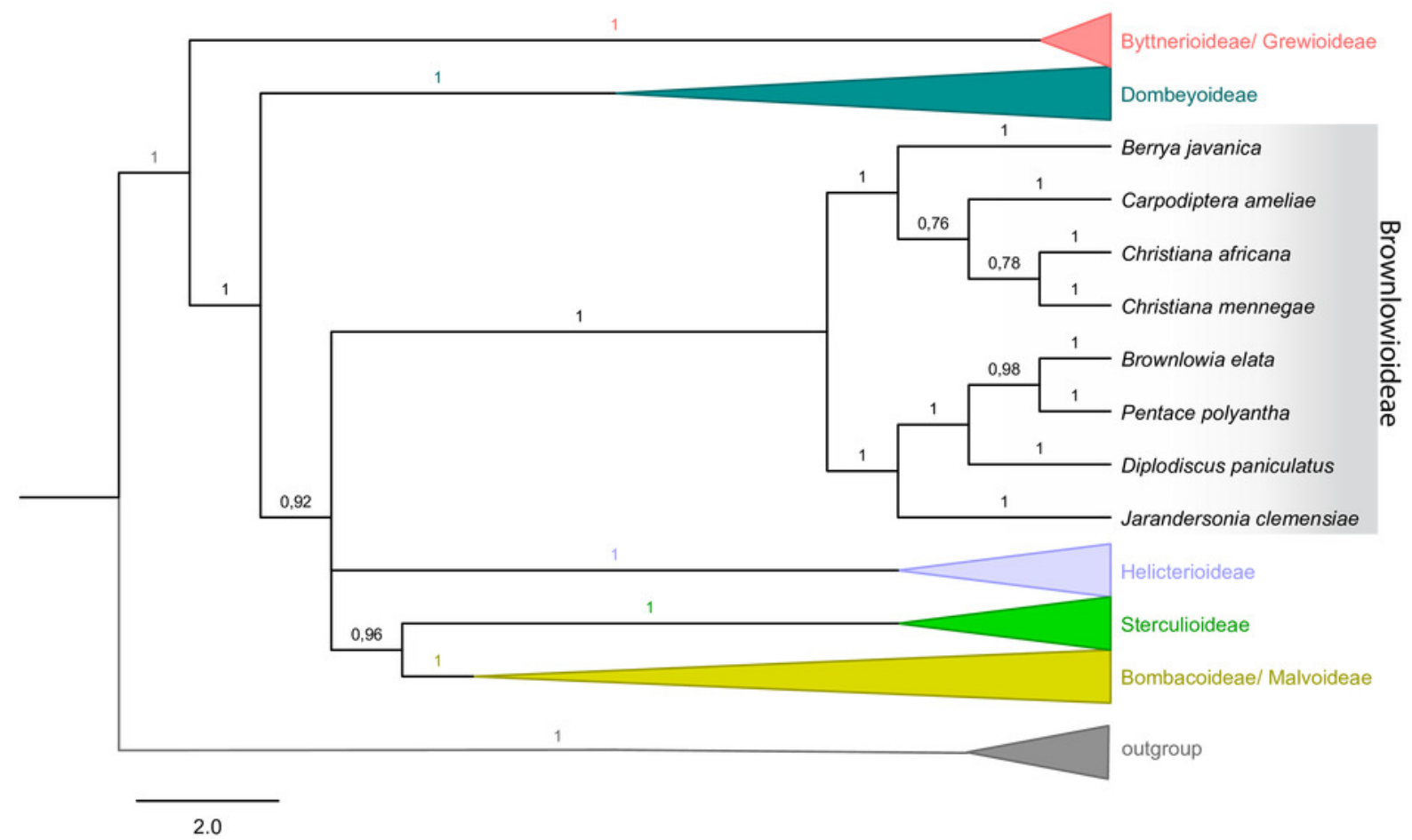




\section{Figure 5}

\section{Christiana mennegae}

(A). Trunk with fissured external bark in male individual. (B) Trunk with lenticellated bark in female individual. (C) Inflorescence with buds and open flower. (D) Fruiting branch. (E) Fruit detail. A and C from Zappi et al. 4562; B, D and E from Barbosa-Silva et al. 1424. 


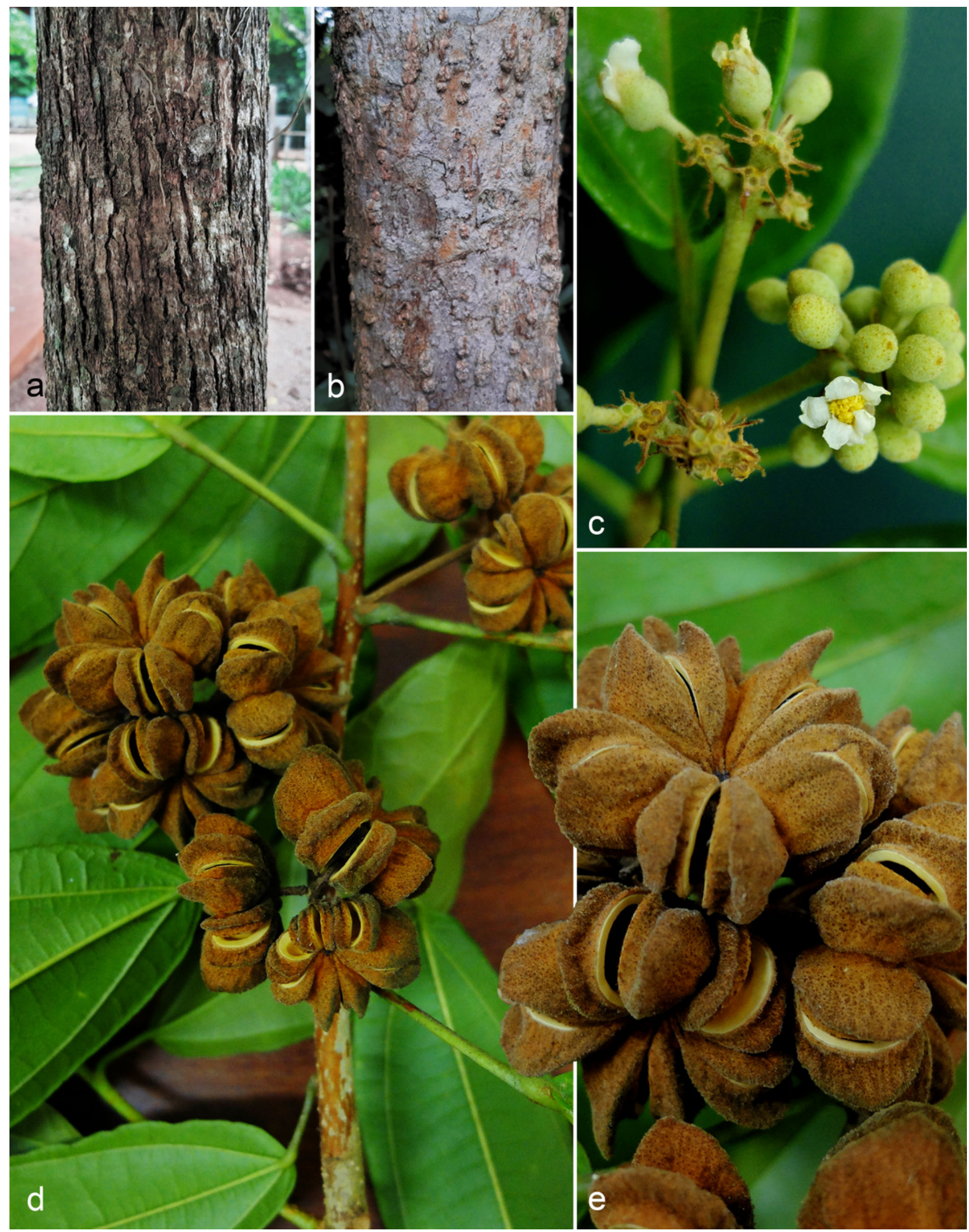

